\title{
Glossary of Terms
}

Ascamah (pl. Ascamot)

Ashkenazi (pl. Ashkenazim)

Ba'al Bayit (pl. Ba’ale Batim)

Goy (pl. Goyim)

Hakham

Halakhah

Haskalah

Ḥeder (pl. Ḥadarim)

Ḥerem

Kashrut

Kehilah (pl. Kehilot)
- bylaw, regulation of a Sephardi (q.v.) synagogue.

- German Polish religious rite or custom, also Jews of central and eastern European origin who follow this rite.

- "householder" (lit.), full member of an Ashkenazi synagogue.

- gentile, frequently used in a derogatory manner.

- rabbi and head of the Sephardi (q.v.) congregations in England.

- "the path" (lit.), the corpus of Jewish law, also a particular area of Jewish law.

- the European Jewish Enlightenment.

- "room" (lit.), traditional Jewish elementary school.

- religious ban or excommunication.

- dietary laws governing which foods are fit for Jewish consumption, and how to prepare such foods.

- "community" or "assembly" (lit.), traditional European Jewish community, also generic term for any Jewish community or congregation. 
xii $\quad$ Glossary of Terms

Mahamad

Maskil (pl. maskilim)

Sephardi (pl. Sephardim)

Sheḥitah

Shoḥet (pl. Shoḥetim)

Takanah (pl. Takanot)

Toshavim

Yeshivah (pl. Yeshivot)

Zedakah
- governing body/executive committee of Bevis Marks, Spanish and Portuguese Synagogue of London.

- proponent of the Haskalah (q.v.).

- Spanish and Portuguese Jewish rite or custom, also Jews from Iberia (and subsequently North Africa and areas of the Middle East) who follow this rite.

- kosher slaughter, i.e., slaughter conducted according to the laws of kashrut (q.v.).

- a kosher slaughterer, one who observes the rules of shehitah (q.v.).

- bylaw, regulation of an Ashkenazi (q.v.) synagogue or kehilah (q.v.).

- "residents" (lit.), seat holders in an Ashkenazi (q.v.) synagogue.

- "sitting" (lit.), traditional Jewish school of higher learning. Exclusively male.

- "righteousness" (lit.), Jewish charity, and the laws governing the giving of alms. 